\title{
30
}

\section{The case for reform of the electoral system in Fiji}

\author{
Rev. David G. Arms
}

Since the time the alternative vote (AV) was first proposed for Fiji in the Reeves Commission's report of 1996, there have been those (such as myself) who opposed it, regarding it as unsuitable to Fiji's political circumstances. Ever since the first elections using AV were held in 1999, there have been calls for reform. A lot of the suggestions being made have to do with improving the AV system as currently designed for Fiji. However, there has also been a consistent call for complete abandonment of the AV system. Between 1999 and 2001 there was a strong push by some for a return to the first-past-the-post (FPP) system, which Fiji had used previously. ${ }^{1}$ Use of FPP would certainly remove the complexities of the present AV system, but it would do nothing at all to overcome AV's other deficiencies. What has been consistently advocated for this purpose is a form of proportional representation (PR). In this chapter, I discuss briefly some of the main arguments for switching to $\mathrm{PR},{ }^{2}$ dwelling at a bit more length on the question of ethnic cross-voting. Needless to say, in arguing for reform, all three elections held under AV must be put under scrutiny, not just that of 2006 .

The main argument for PR, in my view, is one of fairness. In 1999, the coalition led by the Fiji Labour Party (FLP) received a total of 336,868 first preferences, the coalition led by the Soqosoqo Vakavulewa ni Taukei (SVT), a total of 255,690 first preferences. Respectively, they held 46.8 and 35.5 per cent of the first preferences of the whole electorate. Yet when it came to seat 
allocation under AV, the FLP-led coalition received 52 seats, more than five times as many as the STV-led coalition, which received only 10 ! While it is true that $\mathrm{AV}$ is intended to take into account more than just first preferences, the disproportion it provided in this case can in no way be interpreted as reflecting the wishes of the people, which is what an electoral system is supposed to do. The results were grossly unfair, and were certainly a contributing factor to the coup of 2000. A PR system on the other hand would have divided up the seats much more fairly (see Tables 30.1 and 30.2).

Although the above example of unfairness is perhaps the most striking, there are other clear examples of unfairness in all three elections held under AV (1999, 2001, and 2006). Take, for instance, the National Federation Party (NFP), which is mainly an Indo-Fijian-backed party. In 1999 it received a total of 104,676 first preferences, in 2001 a total of 63,915 first preferences, and in 2006 a total of 49,116 . This represents about a third, a quarter, and a seventh respectively of the Indo-Fijian vote. Yet the NFP received no seats at all in any of the three elections. How can this be in any way construed as fair?

Another argument for PR is that AV has failed in the very purpose for which it was adopted. The main reason given by the Reeves Commission for adoption of $\mathrm{AV}$ was to promote multi-ethnic government. ${ }^{3} \mathrm{AV}$ has done nothing of the kind - indeed it has done the very opposite. In 1999, the FLP-led coalition was indeed multi-ethnic and became the government; but every Indo-Fijian in parliament was in the government (except for George Shiu Raj), leaving the opposition benches to be filled by the other ethnic groups (and George Shiu Raj). This was hardly what was envisaged. What made things worse in practice, was that many of the indigenous Fijian members of the government were not happy with developments. Their support slipped away, clearly making the Lower House ethnically divided. In 2001, this division was even more apparent - the government was basically one of indigenous Fijians (and George Shiu Raj), with the other ethnic groups in opposition (with a couple of non-Indo-Fijian MPs, however, opting to join the government).

In 2006, the situation has become worse, with almost everyone alleging that the voting has taken place along ethnic lines - indigenous Fijians voting mainly for the SDL, and Indo-Fijians for the FLP. Indeed, instead of promoting multi-ethnic government parties, as the Reeves Commission had intended, ${ }^{4}$ it 
Table 30.1 1999 election: parties, first preferences and seats

Party

1 st Prefs $\quad \%$

AV

FPP

PR

Fijian communal constituencies:

23 seats, total valid votes 179,216

FAP

$\begin{array}{rrrrr}32,032 & 17.87 & 9 & 4 & 4 \\ 3,352 & 1.87 & - & - & - \\ 16,352 & 9.12 & 1 & 1 & 2 \\ 17,149 & 9.57 & 4 & 4 & 2 \\ 68,114 & 38.01 & 5 & 11 & 10 \\ 34,758 & 19.40 & 3 & 2 & 5 \\ 5,645 & 3.15 & 1 & 1 & - \\ 1,814 & 1.01 & - & - & -\end{array}$

Indian communal constituencies:

19 seats, total valid votes 165,841

FAP

FLP

NFP

PANU

Indep

$\begin{array}{rr}955 & 0.58 \\ 108,735 & 65.57 \\ 53,076 & 32.00 \\ 153 & 0.09 \\ 1,015 & 0.61 \\ 1,907 & 1.15\end{array}$

Other

1,907

1.15

General communal constituencies:

3 seats, total valid votes 11,013

FAP

GVP

UGP

Indep

Other

$\begin{array}{rr}1,057 & 9.60 \\ 3,367 & 30.57 \\ 5,412 & 49.14 \\ 20 & 0.18 \\ 1,157 & 10.51\end{array}$

Rotuman communal constituency:

1 seat, total valid votes 3,994

Indep

Other

$2,012 \quad 50.38$

$1,982 \quad 49.62$

Open constituencies:

25 seats, total valid votes 359,491

FAP

FLP

NFP

NVTL

PANU

SVT

UGP

VLV

Indep

$\begin{array}{rrrrr}38,863 & 10.81 & 2 & 2 & 3 \\ 119,563 & 33.26 & 18 & 15 & 8 \\ 51,600 & 14.35 & - & - & 4 \\ 15,234 & 4.24 & - & - & 1 \\ 14,009 & 3.90 & - & - & 1 \\ 72,726 & 20.23 & 3 & 7 & 5 \\ 4,732 & 1.32 & 1 & 1 & - \\ 35,314 & 9.82 & - & - & 3 \\ 5,323 & 1.48 & 1 & - & - \\ 2,127 & 0.59 & - & - & -\end{array}$


has provided a situation in which each communal group has its own communal party: the SDL for indigenous Fijians, the FLP for Indo-Fijians, the UPP for the Generals, and an Independent for the Rotumans. Only Robin Irwin, for the Generals, forms an exception! Any multi-ethnic government that eventuates will be due to the multiparty cabinet provisions of the constitution (which were not a part of the Reeves report); it will not derive from the AV system. On the other hand, a PR system, while not forcing a multi-ethnic government, presents good opportunities for voluntary coalition formation - and such coalitions are likely to cross ethnic lines.

A further argument for PR is that it promotes the role of women in politics. Of the 15 nations with the highest percentage of women MPs in the Lower House, 14 use PR electoral systems. This speaks for itself. While there are now eight women MPs in the Lower House (which constitutes an improvement over 2001, but is only the same as in 1999), this is far below what is desirable. Women comprise 50 per cent of the population. While parity may not be a practical option, the nation would profit greatly from having women's direct input in governance. $\mathrm{PR}$, not $\mathrm{AV}$, is a practical way of facilitating this. Not only does the system itself give women a better chance of succeeding, but it is easier in PR systems to legislate increased representation for women. For instance, under a list or mixed-member proportional system,

Table 30.2 1999 election: parties, preferences and seats - overall view

\begin{tabular}{lrrrrrr}
\hline Party & 1 st Prefs & $\%$ & AV & FPP & $\begin{array}{c}\text { Com/ } \\
\text { Open PR }\end{array}$ & $\begin{array}{r}\text { 71-Open } \\
\text { PR }\end{array}$ \\
All constituencies: & & & & & & \\
$\quad 71$ seats, total valid votes & 719,555 & & & & 7 & 8 \\
FAP & 71,952 & 10.00 & 11 & 6 & 21 & 24 \\
FLP & 231,650 & 32.19 & 37 & 34 & 1 & - \\
GVP & 3,367 & 0.47 & 2 & - & 10 & 11 \\
NFP & 104,676 & 14.55 & - & - & 3 & 3 \\
NVTL & 31,586 & 4.39 & 1 & 1 & 3 & 3 \\
PANU & 32,266 & 4.48 & 4 & 4 & 15 & 14 \\
SVT & 140,840 & 19.57 & 8 & 18 & 8 & 7 \\
UGP & 10,144 & 1.41 & 2 & 4 & 2 & - \\
VLV & 70,072 & 9.74 & 3 & 2 & - \\
Indep & 14,015 & 1.95 & 3 & 2 & - & - \\
Other & 8,987 & 1.25 & - & - & - & \\
\hline
\end{tabular}


legislation could require that at least one in every four candidates on a party's list be a woman.

Another supporting argument for changing to PR at this time, is that of simplicity. PR systems can of course be complex. But there are PR systems that are quite simple - just one tick, or at most two, on an easy-to-understand ballot paper. The complexity of the AV system is itself a serious issue in Fiji. But is seems pointless to tamper with the system in order to make it simpler when $\mathrm{AV}$ is deficient on other grounds, as indicated above and also below. It would surely be more efficient to adopt a suitable and simple PR system that simultaneously solves those other deficiencies of AV.

Another aspect of PR is that it would have a moderating effect on communalism. This matter is clearly related to the larger topic of multiethnic government. As indicated earlier, the 2006 election is generally looked upon as being very much an ethnic tussle: the SDL supported mainly by indigenous Fijians versus the FLP supported mainly by Indo-Fijians. But AV has exaggerated this bipolar division. And it has also deprived of representation a more accommodating middle ground.

Contrary to public perception, in 2006, more indigenous Fijians voted for the so-called Indo-Fijian parties (FLP and NFP) in the Fijian communal seats than ever before -7.26 per cent of them in fact (see Table 30.5). This compares with 2.8 per cent in 2001 (see Table 30.3) and a measly 1.87 per cent in 1999 (see Table 30.1). This outcome is in spite of the fact that most of the voters would have known that the party they were voting for had no chance of winning the seat. Had there been a real chance of such a vote affecting the outcome (which there would have been under List PR, for example), it is probable that the percentages would have been higher. If List PR had been in operation, the FLP would have picked up two seats from indigenous Fijian votes in 2006, perhaps one seat in 2001, but none in 1999.

There are similarly Indo-Fijian voters in Indo-Fijian communal seats voting for parties viewed as primarily indigenous Fijian. Their numbers were miniscule in 1999 and 2001 because such parties figured it was a waste of time and money trying to compete against the major Indo-Fijian parties. In most Indo-Fijian constituencies therefore, there was no primarily indigenous Fijian party that could be voted for. But the SDL gave it a real try in 2006, and, though their 
Table 30.32001 election: parties, first preferences and seats

Party

1st Prefs \%

AV

FPP

PR

Fijian communal constituencies:

23 seats, total valid votes 166775

BKV

CAMV

FAP

FLP

NFP

NLUP

NVTL

PANU

SDL

SVT

Indep

Other

$\begin{array}{rrrrr}7,826 & 4.69 & - & 1 & 1 \\ 33,776 & 20.25 & 5 & 5 & 5 \\ 3,528 & 2.12 & - & - & - \\ 3,857 & 2.31 & - & - & 1 \\ 817 & 0.49 & - & - & - \\ 6,666 & 4.00 & - & - & 1 \\ 2,738 & 1.64 & - & - & - \\ 4,900 & 2.94 & - & 1 & 1 \\ 83,506 & 50.07 & 18 & 16 & 12 \\ 14,331 & 8.59 & - & - & 2 \\ 4,085 & 2.45 & - & - & - \\ 745 & 0.45 & - & - & -\end{array}$

Indian communal constituencies:

19 seats, total votes 145,431

FAP

FLP

NFP

NLUP

SDL

Indep

Other

$\begin{array}{rr}8 & 0.01 \\ 108,459 & 74.58 \\ 32,143 & 22.10 \\ 3,731 & 2.56 \\ 149 & 0.10 \\ 565 & 0.39 \\ 376 & 0.26\end{array}$

GVP

SDL

SVT

UGP

520

32.45

Indep

Rotuman communal constituency:

1 seat, total valid votes 3,772

Indep

$1,969 \quad 52.20$

Other

$1,803 \quad 47.80$


Table 30.3 continued

Party

1st Prefs

$\%$

AV

FPP

PR

Open constituencies:

25 seats, total valid votes 310,765

BKV

CAMV

FAP

3,750

1.21

30,313

9.76

4,296

1.38

FLP

NFP

NLUP

NVTL

106,412

34.24

30,955

9.96

17,099

5.50

944

0.30

PANU

2,188

0.70

SDL

83,095

26.74

SVT

20,560

6.62

Indep

10,099

3.25

Other

1,054

0.34

Table 30.42001 election: parties, preferences and seats - overall view

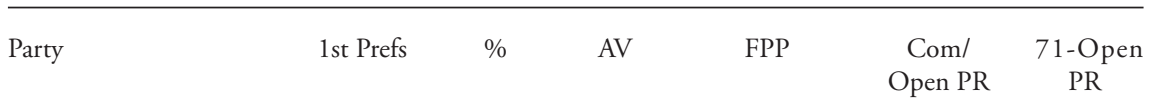

All constituencies:

71 seats, total valid votes 636,788

$\begin{array}{lrrr}\text { BKV } & 11,576 & 1.82 & - \\ \text { CAMV } & 64,414 & 10.12 & 6 \\ \text { FAP } & 8,146 & 1.28 & - \\ \text { FLP } & 218,728 & 34.35 & 27 \\ \text { GVP } & 1,904 & 0.30 & - \\ \text { NFP } & 63,915 & 10.04 & 1 \\ \text { NLUP } & 28,489 & 4.47 & 2 \\ \text { NVTL } & 3,682 & 0.58 & - \\ \text { PANU } & 7,088 & 1.11 & - \\ \text { SDL } & 169,227 & 26.57 & 32 \\ \text { SVT } & 35,143 & 5.52 & - \\ \text { UGP } & 3,260 & 0.51 & 1 \\ \text { Indep } & 17,238 & 2.71 & 2 \\ \text { Other } & 3978 & 0.62 & -\end{array}$


Table 30.52006 elections: parties, first preferences and seats

\begin{tabular}{llllll}
\hline Party & 1 st Prefs & $\%$ & AV & FPP & PR
\end{tabular}

Fijian communal constituencies:

23 seats, total valid votes 203,176

FLP

PANU

NAP

NFP

NVTL

SDL

UPP

Indep

Other

Indian communal constituencies:

19 seats, total valid votes 165,082

$\begin{array}{rrrrr}12,865 & 6.33 & - & - & 2 \\ 4,127 & 2.03 & - & - & - \\ 5,050 & 2.49 & - & - & 1 \\ 1,883 & 0.93 & - & - & - \\ 2,203 & 1.08 & - & - & - \\ 163,799 & 80.62 & 23 & 23 & 20 \\ 115 & 0.06 & - & - & - \\ 13,106 & 6.45 & - & - & - \\ 28 & 0.01 & - & - & -\end{array}$

$\begin{array}{rrrrr}134,002 & 81.17 & 19 & 19 & 16 \\ - & 0.00 & - & - & - \\ 3,170 & 1.92 & - & - & - \\ 23,263 & 14.09 & - & - & 3 \\ - & 0.00 & - & - & - \\ 4,260 & 2.58 & - & - & - \\ - & 0.00 & - & - & - \\ 349 & 0.21 & - & - & - \\ 38 & 0.03 & - & - & -\end{array}$

General communal constituencies:

3 seats, total valid votes 10,809

FLP

PANU

NAP

NFP

NVTL

SDL

UPP

Indep

$383 \quad 3.54$

-0.00
$-\quad 7.18$

$776 \quad 7.18$

$\begin{array}{ll}60 & 0.56\end{array}$

$\begin{array}{rr}- & 0.00 \\ 3,874 & 35.84\end{array}$

$4,220 \quad 39.04$

$1,496 \quad 13.84$

Other

Rotuman communal constituency:

1 seat, total valid votes 4,435

NAP

$245 \quad 5.52$

SDL

$526 \quad 11.86$

UPP

$532 \quad 12.00$

Indep

$3,132 \quad 70.62$

R



20

$-$

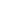


Table 30.5 continued

\begin{tabular}{lrrrrr} 
Party & 1 st Prefs & $\%$ & AV & FPP & PR \\
Open constituencies: & & & & & \\
$\quad 75$ seats, total valid votes 387,407 & & & & & 11 \\
FLP & 156,913 & 40.52 & 12 & 11 & - \\
PANU & 2,099 & 0.55 & - & - & - \\
NAP & 13,363 & 3.46 & - & - & 2 \\
NFP & 23,910 & 6.18 & - & - & - \\
NVTL & 1,454 & 0.39 & - & - & - \\
SDL & 70,952 & 44.14 & 13 & 14 & - \\
UPP & 1,615 & 0.43 & - & - & - \\
Indep & 16,618 & 4.30 & - & - & - \\
Other & 483 & 0.03 & - & - & - \\
\hline
\end{tabular}

success came nowhere near their pre-election hype, it was impressive enough. At their first effort, the SDL were able to pick up 2.58 per cent of the Indo-Fijian vote. This would not have won them a seat under List PR, but it would have come pretty close. What's more, this percentage was obtained even though the SDL would not generally have been considered benign towards Indo-Fijians in its five-year term of government, only going after their vote late in the day.

We see then that there is a certain amount of ethnic cross-voting. There could, in fact, be quite a lot of such cross-voting in the open seats, but since voting is done in secret, any estimate of the percentage of cross-voting in open seats would be largely guesswork. In the communal seats, however, even though cross-voting may be on a small scale, it has significantly increased in 2006. The big problem is that $\mathrm{AV}$ is not rewarding these votes in any way, whereas List PR would do so. AV is in fact misrepresenting Fiji's voters, and misleading them into believing that Fiji has become more polarized, whereas the truth is the opposite. The tragedy is that the continued use of AV is highly likely to bring about and intensify this polarization. Why would parties like the SDL and FLP continue to spend money and make efforts to draw cross-ethnic votes in the communal seats when AV makes such efforts futile? What is said here about communal seats will also apply to many open seats. As about 20 of these 25 seats are ethnically lop-sided, and it is predictable which party will win, there may soon be a tendency by the party of the other ethnic group not to contest them, for such effort will also be seen as futile. This is why an immediate change to PR becomes so important. Fiji needs to build on what willingness there is to vote across ethnic boundaries, not discourage it. 
Unfortunately, AV discourages other smaller parties too, some of which occupy the middle ground between the two giants. The NFP and NAP (National Alliance Party) are excellent examples. Though they drew 49,116 first preferences (as mentioned earlier) and 22,604 first preferences, respectively, in 2006 (see Table 30.6), they received no reward, whereas under PR they would have (the reward would have been five seats for the NFP and two seats for the NAP). Why keep the AV system, which wipes out such minority viewpoints? Such parties, though small, have a valuable contribution to make. Who can deny the value of the United Generals Party (UGP) - now the United Peoples Party (UPP) - in parliament, for example? Though the party had a solitary representative in the last parliament, it wielded substantial and constructive influence. But notice again AV's abhorrently haphazard nature. While we may rue the failure of the NFP and NAP to win any seats, even with their large number of first preferences, the UPP with only 6,482 first preferences in 2006 managed to win two! What a ridiculous perversion of justice!

To cut out certain minorities in this way is against Fiji's own cultural norms. Fiji prides itself on its respect for minorities - except, it would appear, when they are political parties. Rotumans receive a place in the Senate and their own Lower House seat; the Generals are very well catered for with three seats; provinces such as Serua and Namosi receive separate Fijian communal seats even though

Table 30.62006 elections: parties, preferences and seats - overall view

\begin{tabular}{|c|c|c|c|c|c|c|}
\hline Party & 1st Prefs & $\%$ & AV & FPP & $\begin{array}{c}\text { Com/ } \\
\text { Open PR }\end{array}$ & $\begin{array}{c}\text { 71-Open } \\
\text { PR }\end{array}$ \\
\hline
\end{tabular}

All constituencies:

71 seats, total valid votes 770,909

\begin{tabular}{lrrrrrr} 
FLP & 304,163 & 39.46 & 31 & 30 & 29 & 29 \\
PANU & 6,226 & 0.81 & - & - & - & 1 \\
NAP & 22,604 & 2.93 & - & - & 2 & 2 \\
NFP & 49,116 & 6.37 & - & - & 5 & 5 \\
NVTL & 3,657 & 0.47 & - & - & - & - \\
SDL & 343,411 & 44.55 & 36 & 38 & 32 & 33 \\
UPP & 6,482 & 0.84 & 2 & 2 & 2 & 1 \\
Indep & 34,701 & 4.50 & 2 & 1 & 1 & - \\
Other & 549 & 0.07 & - & - & - & - \\
\hline
\end{tabular}


their population is far smaller than many other provinces; proportionality is required for deciding seats in the multiparty cabinet; proportionality is also required in deciding which opposition members will be appointed to the Senate. There seems to be in all these cases a genuine concern for inclusiveness. Such an attitude is necessary also toward political parties.

PR would provide this inclusiveness, as well as the fairness spoken of earlier. At the same time, it would not exaggerate the importance of such parties. By being proportional it gives all groups their due. It may be thought that, while AV and FPP may tend to push politics too much into a two-party struggle, PR would multiply parties excessively and thus make governance too difficult. Experience in other countries, however, does not bear this out. There may indeed be a need for more comprehensive dialogue, but surely that is often what is best for a country. It is, in fact, precisely what is being called for in Fiji's current multiparty cabinet situation.

However, can we realistically expect the two major parties, the SDL and the FLP, to opt for a change to PR when it would clearly weaken their overall power? To get them to do so will certainly be a challenge, but it should be attempted for the good of the country. Hopefully, the leadership of these two parties, especially in a multiparty cabinet context, will have enough statesmanship to give this consideration due priority.

Self-interest, however, would also indicate that these parties consider PR. ${ }^{5}$ As Fiji's demographics change with the emigration of Indo-Fijians, the FLP's main power-base is shrinking. PR would ensure that it would retain fair representation no matter what happens in regard to population ratios in the future. On the other hand, the SDL needs to consider that, as fear of Indo-Fijian leadership subsides in the indigenous community, more internal differences (especially, perhaps, regional ones) are likely to emerge within that community, as has happened before (in the first 1977 election with Sakeasi Butadroka, and in the 1994 election with Josefata Kamikamica). If splits occur in indigenous Fijian politics, it is important that the resulting factions be represented fairly, otherwise the injustice of the 1999 election towards the SVT-led coalition could be repeated for the SDL and/or the dissident factions.

While PR cannot be expected to solve all of Fiji's political difficulties, it would help the country enormously in the various ways suggested here. 


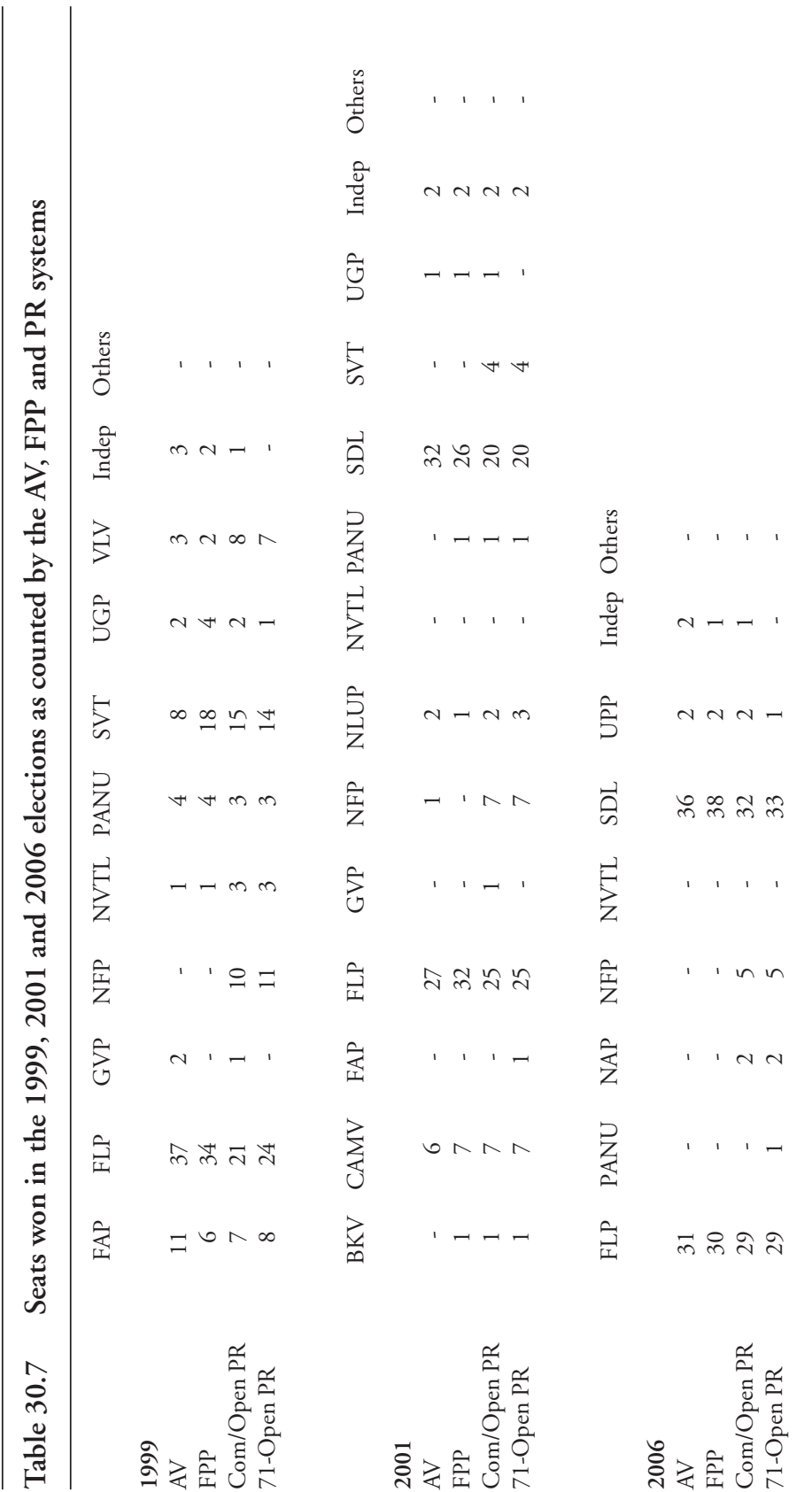




\section{A note on the electoral data}

Tables 30.1, 30.3 and 30.5 deal respectively with the elections of 1999, 2001 and 2006. Each table provides the abbreviated names of the political parties, the number of first preferences each party received, the percentage of the ethnic (or joint) group vote that figure represents, the actual number of seats won by each party under the AV system, the number of seats each party would have won if the votes had been counted under Fiji's former FPP system, and the number of seats each party would have won if the allocation was proportional to the number of first preferences each party received. This latter way of allocating seats is one method of what is called proportional representation (PR). ${ }^{6}$

Tables 30.2, 30.4 and 30.6 summarize Tables 30.1, 30.3 and 30.5, respectively, adding together the first preferences and seats for all the different constituency types. These three tables have two PR columns, not just one. The first of these (titled Communal/Open PR) summarizes the PR seats allotted in Tables 30.1, 30.3 and 30.5. In those tables, PR was applied separately within the respective group of constituencies, Communal and Open. PR could be applied in this way, and would indeed work quite well if communal seats were retained. In point of fact, however, it becomes unnecessary to retain communal seats when PR is used, for PR itself provides fair ethnic representation between the various ethnic groups, if this is what the voters themselves want (that is, if they vote along ethnic lines).

The second PR column (titled 71-Open PR) calculates the proportions as if all 71 seats were open seats. It uses the totals of each party's first preferences, Communal and Open, to determine how the 71 seats might have divided out proportionally. There is an inherent weakness in calculating the proportions in this way, however, in that independent candidates and some parties (e.g. the UGP/UPP) will have run in one half of the system (say, the Communal) but not in the other. Similarly, some voters may have been constrained in their voting by the number of parties running in their constituency. Nevertheless, it gives us a rough idea as to how PR results might look. One could, of course, calculate how the 71 seats might have divided up on the basis of the 25 open seats alone, but this would have the same weakness as that described above.

Table 30.7 provides an overall view of the seat division under AV, FPP, Communal/Open PR and 71-Open PR for all three elections. 
What I would particularly like the reader to consider in these seven tables, is the very different seat allocations provided by the three different voting systems. Election results are supposed to reflect 'the will of the people', but clearly that will is interpreted by the voting system used. Surely we should look for a system that reflects that will most accurately. The tables illustrate how the AV and FPP systems provide us with gross inequities in representation. In contrast, a PR system would respect the various opinions in our midst and contribute to a greater degree of collaboration (rather than winner-takes-all). Such working together is what the multiparty cabinet provisions of the constitution are trying to encourage. For large and small groups alike, PR provides genuine and fair representation. The Lower House, after all, is supposed to be a house of representatives.

\section{Notes}

1 Interest in a return to FPP waned after 2001, probably for reasons given in footnote 5.

2 There are three main forms of PR: a list system; a mixed-member proportional system; and a single transferable vote system. Any of these would be fine for Fiji provided they are suitably adapted for Fiji's circumstances. I have elsewhere made concrete suggestions in this regard (see Arms, D.G. 2006. 'Concrete options for proportional representation in Fiji', in Reviewing Fiji's Electoral System, proceedings of workshop hosted by the Citizens' Constitutional Forum, 9-10 February, Printhouse, Suva, pp.9-119; and Arms, D.G. 2006. 'The failure of the alternative vote system and the case for proportional representation in Fiji' in Journal of Pacific Studies).

3 Fiji Constitution Review Commission. 1996. The Fiji Islands: Towards a United Future, Parliament of Fiji Parliamentary Paper 34, Government Printer, Suva, p.310.

4 Reeves Commission 1996, p.315-17.

5 Unfortunately, self-interest is all too often the over-riding factor - a self-interest which is frequently misguided. The indigenous Fijian leadership was in favour of changing back to FPP from AV in the period 1999-2001. The SVT would certainly have done much better under FPP in 1999 (see Table 30.2). However, if FPP had been used in 2001, the FLP would have won, not the SDL (see Table 30.4). There was, thus, little talk of a change back to FPP after 2001. Ironically, had the SDL implemented such a change, the party would have won by a large absolute majority in 2006 (see Table 30.6) rather than by an extremely narrow one.

6 The Sainte Laguë method has been used for the proportional allocation of seats. 